14 Link BG, Phelan JC, Bresnahan M, Stueve A, Pescosolido BA. Public conceptions of mental illness: labels, causes, dangerousness, and social distance. Am J Public Health 1999; 89: 1328-33.

15 Morgan A, Jorm A. Awareness of beyondblue: the national depression initiative in Australian young people. Australas Psychiatry 2007; 15: 329-33.

16 Wolf G, Pathare S, Craig T, Leff J. Community attitudes to mental illness. Br J Psychiatry 1996; 168: 183-90.

17 Watson AC, Miller FE, Lyons JS. Adolescent attitudes toward serious mental illness. J Nerv Ment Dis 2005; 193: 769-72.
18 Davidson J. Contesting stigma and contested emotions: personal experience and public perception of specific phobias. Soc Sci Med 2005; 61: 2155-64.

19 Wang J, Fick G, Adair C, Lai D. Gender specific correlates of stigma toward depression in a Canadian general population sample. J Affect Disord 2007; 103: $91-7$.

20 Cotton S, Wright A, Harris MG, Jorm AF, McGorry PD. Influence of gender on mental health literacy in young Australians. Aust N Z J Psychiatry 2006; 40: 790-6

21 Stier A, Hinshaw SP. Explicit and implicit stigma against individuals with mental illness. Aust Psychol 2007; 42: 106-17.

\title{
I am by John Clare (1793-1864)
}

\section{Chosen by Robert Howard}

I am was written in 1844 or 1845 by John Clare in the Northampton General Lunatic Asylum (now St Andrew's Hospital). Now regarded as one of the 19th century's most important poets, Clare's rural working class origins led to his being dubbed 'the Northamptonshire Peasant Poet'. Overtaken by poverty and a chronic psychotic illness he was incarcerated in mental hospitals from 1837 until his death. In the poem Clare struggles to conquer the effects of his illness through assertion of his individuality and faith that he will ultimately find a spiritual peace.

I am: yet what I am none cares or knows, My friends forsake me like a memory lost;

I am the self-consumer of my woes,

They rise and vanish in oblivious host,

Like shades in love and death's oblivion lost;

And yet I am! and live with shadows tost

Into the nothingness of scorn and noise,

Into the living sea of waking dreams,

Where there is neither sense of life nor joys,

But the vast shipwreck of my life's esteems

And e'en the dearest - that I loved the best -

Are strange - nay, rather stranger than the rest.

I long for scenes where man has never trod;

A place where woman never smil'd or wept:

There to abide with my creator, God,

And sleep as I in childhood sweetly slept:

Untroubling and untroubled where I lie;

The grass below - above the vaulted sky. 